\title{
The study of cobalt leaching from soils, sewage sludges and composts using a one-step extraction
}

\author{
Badanie wymywalności kobaltu z gleb, osadów ściekowych \\ i kompostów przy wykorzystaniu ekstrakcji jednostopniowej
}

${ }^{*}$ Dr inż. Marta Bożym, Faculty of Mechanical Engineering, Department of Environment Engineering, The Opole University of Technology, Mikołajczyka 5St., 45-271 Opole, Poland, e-mail:m.bozym@po.opole.pl
${ }^{* *}$ Mgr inż. Agnieszka Rajmund, Institute of Technology and Life Sciences, Lower Silesia Research Centre in Wroclaw, Zygmunta Berlinga 7St., 51-209 Wrocław, Poland

Keywords: sewage sludge, compost, soil, cobalt, one-step extraction

Słowa kluczowe: osady ściekowe, kompost, gleba, kobalt, specjacja jednostopniowa

\begin{abstract}
The study evaluated the leaching of cobalt (Co) in soils fertilised with sewage sludge (SS) and composts depending on the extractant used. SS came from rural, mechanical-biological treatment plant in Dobrzeń, Lower Silesia region. In addition, those SS were processed by composting. Sludges and composts were used to fertilise the energy plants during lysimeter experiment conducted during 2008-2013. The overall, as well as extracted by $\mathrm{H}_{2} \mathrm{O}, 0.1 \mathrm{M} \mathrm{HCl}$ and $1 \mathrm{M} \mathrm{HCl}, 0.05 \mathrm{M} \mathrm{Na}_{2}$ EDTA and $0.1 \mathrm{M} \mathrm{Na} \mathrm{NaDTA}_{2}$, content of $\mathrm{Co}$ in samples were analysed. Additionally, the impact of $\mathrm{pH}$ and organic matter (OM) content on the leachability of Co were researched. It was found that the soil samples were rich in Co. Its share slightly depended on fertilisation with SS and compost. Co leaching depends on the type and concentration of extractant. The highest content of Co were leched with $0.1 \mathrm{M} \mathrm{Na}_{2} E D T A$, and the lowest content with $0.1 \mathrm{M} \mathrm{HCl}$. Co concentration in $\mathrm{H}_{2} \mathrm{O}$ extracts was not determined as its content was below the limit of quantification. Leachability of $\mathrm{Co}$ in the analysed samples was influenced by the overall Co content as well as $\mathrm{pH}$ and $\mathrm{OM}$ content.
\end{abstract}

(C) IOŚ-PIB

\section{INTRODUCTION}

Heavy metal mobility and bioavailability in sediments depend strongly on the mineralogical and chemical forms in which they occur. Extraction techniques are used to evaluate the mobility of heavy metals in environmental samples. The analysis allows determining the content of different forms of metals relative to their total concentration. This is useful, for example, for assessing the migration of metal ions from the sewage sludge (SS) and soils to plants [5, 26]. Different extraction reagents to leaching metals are used to assess their bioavailability in solid samples. Many methods are prepared to determine the mobility of the metals in different parts of the environment (sediments, soils, SS, waste et al.). Methods for chemical leaching of metals can be divided into single- (one-step) or multi-stage (sequential) extraction. One-step extraction tests are commonly used to study the ecotoxicity and mobility of metals in environmental samples. This method allows an assessment of bioavailability

\section{Streszczenie}

W pracy dokonano oceny wymywalności kobaltu w glebach nawożonych osadami ściekowymi i kompostami osadowymi w zależności od wykorzystanego ekstrahentu. Osady ściekowe pochodziły z wiejskiej, mechaniczno-biologicznej oczyszczalni ścieków w Dobrzeniu, województwo dolnośląskie. Dodatkowo osady poddawano kompostowaniu. Osady i komposty stosowano do nawożenia roślin energetycznych w doświadczeniu lizymetrycznym prowadzonym w latach 2008-2013. W próbkach zbadano zawartość ogólną kobaltu oraz po ekstrakcji $\mathrm{H}_{2} \mathrm{O}, 0,1 \mathrm{M}$ $\mathrm{HCl}$ i $1 \mathrm{M} \mathrm{HCl}, 0,05 \mathrm{M} \mathrm{Na}_{2}$ EDTA i 0,1M Na $\mathrm{EDT}_{2}$. Dodatkowo oceniono wpływ pH i zawartości substancji organicznej na wymywalność kobaltu. Stwierdzono, że badane gleby były zasobne w kobalt. Jego udział w niewielkim stopniu zależał od nawożenia osadem ściekowym i kompostem. Wymywalność kobaltu zależała od rodzaju i stężenia ekstrahentu. Najwięcej kobaltu wymyto przy roztworu $0,1 \mathrm{M} \mathrm{Na}_{2}$ EDTA, natomiast najmniej $0,1 \mathrm{M} \mathrm{HCl}$. W wyciągach wodnych nie oznaczono zawartości kobaltu, jego udział znajdował się poniżej granicy oznaczalności. $\mathrm{Na}$ wymywalność $\mathrm{Co} \mathrm{z}$ badanych próbek wpłynęła zawartość ogólna tego metalu, odczyn pH i zawartość substancji organicznej.

of metals and environmentally accessible trace metals upon disposal of wastes on a soil, thus assessing contamination of ground waters [1]. The method is most often used for soil speciation analysis. It makes it possible to determine the content of phytoavailable forms that were taken up by the plant. The advantage of one-step extraction is primarily a short time of analysis. In the sequential extraction (speciation), separation techniques in different forms of the matrix metal are used. Sequential extraction procedures are commonly applied, because they provide information on the fractionation of metals in the different lattices of the solid sample and to give information on environmental contamination risk. The advantages of these methods are more accurate estimation of the chemical forms of metals and easier prediction of their bioavailability. The disadvantage is the time and the need to use several extractants. For this reason, in 1987, the European 
Community Standards, Measurement and Testing Programme (SM\&T, preciously BCR) was started during which several research projects were implemented in which many laboratories throughout Europe took part. The result of the programme was to standardise the techniques of separation of metals in soils and sediments and the development of a three-step extraction method [24]. A large number of different reagents, that can extract almost all or part of the metals commonly found in soils $\left(\mathrm{H}_{2} \mathrm{O}\right.$, salts as $\mathrm{NaNO}_{3}, \mathrm{NH}_{4} \mathrm{NO}_{3}, \mathrm{KNO}_{3}, \mathrm{CaCl}_{2}, \mathrm{CH}_{3} \mathrm{COONH}_{4}$, chelating agents as EDTA, DTPA and acids $\mathrm{CH}_{3} \mathrm{COOH}$, $\mathrm{HNO}_{3}, \mathrm{HCl}$ ) have been used. In many European countries, it is recommended to use different extractant to exchangeable metal determination in soils. For example, in Germany $1 \mathrm{M}$ $\mathrm{NH}_{4} \mathrm{NO}_{3}$, in Switzerland 0.1M NaNO${ }_{3}$, in the Netherlands $0.01 \mathrm{M}$ $\mathrm{CaCl}_{2}$, in France DTPA (NFX 31-121) and $1 \mathrm{M} \mathrm{NH}_{4} \mathrm{OAc}$ (French standard NF X 31-108) are used. In Poland, $1 \mathrm{M} \mathrm{HCl}$ are used in the assessment of potential bioavailability of micronutrients in soils [16].

Single extractants can be considered for their role of releasing elements from particular solid samples phases with which they are bound or associated [17]. However, single extraction is seldom used, because they are not sufficiently specific [9]. Leaching of metals depends on the type of eluent. Water-soluble metal ions can easily be mobilised, and may be considered as highly available $[18,26]$. This extractants contain the watersoluble species made up of free ions and ions complexed with soluble organic matter (OM). Usually the concentration of trace metals in the soil solution is very low [17]. Higher degree of elution characterised by inorganic acids $\left(\mathrm{HNO}_{3}, \mathrm{HCl}\right)$, followed by complex (chelates) (Ethylenediaminetetraacetic acid - EDTA or Diethylenetriaminepentaacetic acid DTPA) and salt solutions [21]. Complex extraction solutions have been developed to ascertain bioavailability of heavy metals. Complexation by EDTA and other chelates are thought to simulate complexing behaviour of root exudates. Extractions using EDTA solution are widely used in ecochemical evaluations and more particularly those involving plant uptake. Complexing extractants such as EDTA or DTPA solutions can displace metals from insoluble organic or organometallic complexes in addition to those sorbed on inorganic components of solid phase. Those solutions attack the aluminosilicate structure, or Fe-bearing silicates minimally $[11,21,23]$. The elution ratio of metals by chelating agents such as EDTA, is influenced by the concentration, temperature and extraction time. The metal content of these extracts is strongly correlated with participation in plants. Therefore, the chelating agent is most often used to evaluate the bioavailability of metals in the soil $[1,17,25]$. EDTA is a stronger extractant than other chelating agents such as DTPA, hydroxyethyenediaminetriacetic acid (HEDTA), nitrilotriacetic acid (NTA) or ethylene glycol tetraacetic acid (EGTA) [4]. It was also shown that EDTA can release more metals from soils than inorganic acids [3]. Extractable metals by inorganic acids $\left(\mathrm{HNO}_{3}, \mathrm{HCl}\right)$ have been suggested as a measure for geochemically active metals presented in solid samples. Hydrochloric acid $(\mathrm{HCl})$ dissolves large amounts of trace elements, far in excess of the nutritional needs of plants. Therefore, it is often criticised [14]. In Poland, the method with $1 \mathrm{M} \mathrm{HCl}$ is used to assess the potential bioavailability of metals in soils. Some authors suggest that the use of $\mathrm{HCl}$ at such a high concentration allows only to determine the 'pseudo-total' metal content in solid samples. For this reason, it is proposed to replace the $1 \mathrm{M} \mathrm{HCl}$ solution having a lower concentration of this acid $(0.1$ $\mathrm{M} \mathrm{HCl})[3,12,13]$.

Cobalt (Co) belongs to the important micronutrients necessary for plant life [10]. In Polish SS the content of Co contains within 2-40 mg kg-1 d.m. However, rarely exceeds content $25 \mathrm{mg} \mathrm{kg}^{-1}$ d.m. For comparison, typically contains manure: $0.22-0.78 \mathrm{mg}$ $\mathrm{kg}^{-1}$ d.m. [6]. The UK and Switzerland set a limit of Co in the sludge used for agricultural uses at $100 \mathrm{mg} \mathrm{kg}^{-1} \mathrm{~d}$.m. France allowed for agricultural use of SS containing not more than $20 \mathrm{mg} \mathrm{kg}^{-1}$ d.m. [19]. Siuta i Wasiak [19] proposed Polish limit values for $\mathrm{Co}$ in SS on $50 \mathrm{mgCo} / \mathrm{kg} \mathrm{d}$.m. The authors suggest that the sludge contain a higher content of cobalt could be used for purposes other than agricultural uses, and even cobalt fertilisation of agricultural land. The content range in the tissues of plants is in the range of $0.02-1 \mathrm{mg} \mathrm{kg}^{-1} \mathrm{~d}$.m. The phytotoxic effect depends on the plant species. Toxic effects of Co in plants revealed drooping leaves, growth inhibition, chlorosis, leaf curling and a reduction in the weight of shoots $[7,10]$.

The aim of the study was to evaluate the leaching of Co in soils fertilised with SS and composts depending on the type of extractant.

\section{MATERIAL AND METHODS}

Research material consisted of soil fertilised with SS and the composts. SS came from rural, mechanical-biological treatment plant with a capacity of $160 \mathrm{~m}^{3} \cdot \mathrm{d}^{-1}$. Sewage is located in Dobrzeń, Lower Silesia region. SS were treated (composted) with the addition of structural materials (grass and sawdust). Composting process of SS was performed within Lower Silesia Research Centre in Wroclaw. Composting was carried out in heaps, on a specially prepared compost area. The proportion of fertiliser was calculated in each case, taking into account the ratio of carbon to nitrogen ( $\mathrm{C}: \mathrm{N})$. Sludges and composts were used to fertilise the energy plants in lysimeter experiment conducted during 2008-2013. Samples of soils, sludges and composts were collected once a year, before fertilisation of soils. After drying and grinding, the samples were analysed. The $\mathrm{pH}$ of the samples was determined in $\mathrm{KCl}$ and $\mathrm{OM}$ content by gravimetric method at $550^{\circ} \mathrm{C}$. The samples were digested in a Microwave Digestion System Millestone Start $D$ in closed teflon bombs. For determination of 'pseudo-total' Co concentrations in soil, SS and compost samples were digested in aqua regia $\left(1: 3 \mathrm{HNO}_{3} / \mathrm{HCl}\right)$. The name 'pseudo-total' concentration of metals in environmental samples was proposed by Rao et al. [17] and Meers et al. [13]; it means of the total metals content in solid samples, except metals associated in silicates crystal structures. 'Pseudo-total' content gives an assessment of the maximum potential hazard that could occur in long term or in extreme environmental regimes.

In addition, mobile forms of Co was also researched. The availability of Co was measured using $\mathrm{H}_{2} \mathrm{O}, 0.1 \mathrm{M} \mathrm{HCl} \mathrm{i} 1 \mathrm{M} \mathrm{HCl}$, $0.05 \mathrm{M} \mathrm{Na}_{2}$ EDTA i $0.1 \mathrm{M} \mathrm{Na}{ }_{2}$ EDTA, The extraction with deionised water was performed within 24 hours at room temperature, the mass ratio of 1:10, in accordance with PN-EN 12457-2:2006 
[15].The extraction with $\mathrm{HCl}(0.1 \mathrm{M} \mathrm{i} 1 \mathrm{M})$ and chelating solution $\mathrm{Na}_{2}$ EDTA $(0.05 \mathrm{M}$ i $0.1 \mathrm{M})$, was performed within 1 hour at room temperature, the mass ratio of $1: 10[8,11,16]$.

All analyses were performed in triplicate. Obtained results were statistically verified by Statistica 10 programme for significance level $P<0.05$. Correlation coefficients $(r)$ were calculated for the relation between concentration of $\mathrm{Co}$ in extract solutions and 'pseudo-total', $\mathrm{pH}, \mathrm{OM}$ contents in samples (linear and multivariate regression). For quality control of total metal content determination in the samples, certified reference materials (CRM) were also analysed using the method for analysing 'pseudototal' content as described above. Two CRM were analysed: 'SS amended soil' CRM005-050 and 'Metals in soil' CRM028-050 (Tusnovics). The recovery of Co content in CRM were $96 \%$ and $91 \%$, respectively.

\section{DISCUSSION}

The $\mathrm{pH}_{\mathrm{KCl}}$ of the $\mathrm{SS}(7.0-7.9)$ was slightly higher than the compost sedimentary (6.1-7.1). The soils were characterised by a slightly acidic $\mathrm{pH}_{\mathrm{KCl}}$ level (6.0-6.6). Fertilisation did not affect significantly change of soil $\mathrm{pH}_{\mathrm{KCl}}$. The content of $\mathrm{OM}$ in $\mathrm{SS}$ ranged from $64 \%$ to $76 \%$, while composts from $53 \%$ to $66 \%$. The content of OM (OM) in the non-fertilised soil ( 1 1) ranged from $1.43 \%$ to $1.8 \%$. In fertilised soils, OM content ranged from $1.6 \%$ to $3.1 \%$ (S2) and $1.6 \%$ to $2.7 \%$ (S3). Over the years, the experiment found a gradual increase in the content of OM in fertilised soils.

Table 1 shows the averaged results (2008-2013) of Co content in SS and composts. Contents in SS (SS) and composts (Ct) differed depending on the date of sampling (SS 4.58-15.09 mg $\mathrm{kg}^{-1}$ d.m. and Ct 4.79-8.25 $\mathrm{mg} \mathrm{kg}^{-1}$ d.m.) (Table 1). Symanowicz and Kalembasa (2010) [20] have determined the amount of Co in SS at the level of $5.1 \mathrm{mg} \mathrm{kg}^{-1} \mathrm{~d}$.m. and $8.2 \mathrm{mg} \mathrm{kg}^{-1} \mathrm{~d}$.m., while Środa et al. (2013) [22] has determined a higher content of that metal in SS (10.9-13.9 $\mathrm{mg} \mathrm{kg}^{-1}$ d.m.).

The Co content in the soil was at the same level regardless of the method of fertilisation (2.23-2.31 $\mathrm{mg} \mathrm{kg}^{-1} \mathrm{~d}$.m.). In

Table 1. Average $(\bar{x}), \mathrm{SD}$ and range of Co 'pseudo-total' content in samples: soils (S1-3), SS and composts (Ct) $\left[\mathrm{mg} \mathrm{kg}^{-1} \mathrm{~d} . \mathrm{m}\right.$.]

\begin{tabular}{|c|c|c|}
\hline \multirow{2}{*}{ Type of sample } & \multicolumn{2}{|c|}{$\begin{array}{c}\text { 'Pseudo-total' } \\
\text { content of Co }\end{array}$} \\
\cline { 1 - 3 } & $\bar{x} \pm$ SD & \multicolumn{1}{|c|}{ Range } \\
\hline SS & $6.65 \pm 4.14$ & $4.58-15.09$ \\
\hline Ct & $5.99 \pm 1.57$ & $4.79-8.25$ \\
\hline Soil 1 (S1) & $2.23 \pm 0.35$ & $1.67-2.96$ \\
\hline Soil 2 (S2) & $2.26 \pm 0.34$ & $1.90-3.05$ \\
\hline Soil 3 (S3) & $2.31 \pm 0.27$ & $1.64-2.93$ \\
\hline
\end{tabular}

SD: Standard deviation; SS: Sewage sludges

S1 - soils without fertilisation

S2 - soils fertilised with compost

S3 - soils fertilised with sewage sludge
Canada, regulations for the concentration of $\mathrm{Co}$ in soils depend on the background considered: $0.01 \mathrm{mgCo} \mathrm{kg}^{-1} \mathrm{~d}$.m. for natural content, $0.04 \mathrm{mg} \mathrm{kg}^{-1} \mathrm{~d}$.m. for agricultural purposes; $0.05 \mathrm{mgCo}$ $\mathrm{kg}^{-1}$ for residential purposes; $0.3 \mathrm{mg} \mathrm{kg}{ }^{-1} \mathrm{~d} . \mathrm{m}$. for industrial purposes. The European Union is working to standardise the chemical status of the soil in order to assess the environmental risk by anthropopression [7]. According to Kabata-Pendias i Pendias (1999) [10] Co content in Polish soils ranged: $0.5-10 \mathrm{mg} \mathrm{kg}^{-1} \mathrm{~d}$.minsandysoils, $5-25 \mathrm{mg} \mathrm{kg}^{-1} \mathrm{~d}$.m. inheavysoilsand $0.2-30 \mathrm{mg} \mathrm{kg}^{-1} \mathrm{~d}$.m. in organic soils. Comparing the results with literature data, it can be concluded that the analysed soils were rich in Co.

In order to evaluate the mobility of Co, the samples were leached using five different aggressive extractants. Water extracted the smallest amounts of metals compared with the other extraction media The content of $\mathrm{Co}$ in the water extracts in all samples was below the limit of quantification ( $<0.2 \mathrm{mg} \mathrm{kg}^{-1}$ d.m.). $\mathrm{HCl}$ extracts low cobalt content $(4-5 \%$ for $0.1 \mathrm{M} \mathrm{HCl}$ and $5-6 \%$ for $1 \mathrm{M} \mathrm{HCl}$ of the 'pseudo-total' were determined in SS and compost samples. Higher concentration of Co was determined in EDTA solutions. Whereas, in SS and compost samples, chelating agent $\left(\mathrm{Na}_{2}\right.$ EDTA) leached higher amounts of $\mathrm{Co}$ than $\mathrm{HCl}$. Co showed the quantities extracted with $0.1 \mathrm{M} \mathrm{Na} \mathrm{N}_{2}$ EDTA highest ( $55 \% \mathrm{SS}$ and $31 \% \mathrm{Ct}$ of the 'pseudo-total') than $0.05 \mathrm{M} \mathrm{Na}_{2}$ EDTA highest ( $37 \%$ SS and $23 \%$ Ct of the 'pseudo-total') (Fig. 1).

The degree of leaching of Co from soil was similar regardless of the method of fertilisation. The higher percentage of the total metal content was found in the extracts: $0.1 \mathrm{Na}_{2}$ EDTA (61-63\%), followed $0.05 \mathrm{Na}_{2}$ EDTA (34-36\%), $1 \mathrm{M} \mathrm{HCl}(17-21 \%)$ and $0.1 \mathrm{M}$ $\mathrm{HCl}(11-12 \%)$. Chelates, extractants such as EDTA, aim to remove metals chelated by $\mathrm{OM}$ and $\mathrm{Fe}-\mathrm{Mn}$ oxides, associated with Co [7, 8]. Greinert (2011) [7] presents a higher level of soil leaching of $\mathrm{Co}$ extracted by $\mathrm{HCl}: 18-25 \%$ for $0.1 \mathrm{M} \mathrm{HCl}$ and $52-66 \%$ for $1 \mathrm{M} \mathrm{HCl}$. The author said that the level of eluted Co from the soil affects the type of extractant.

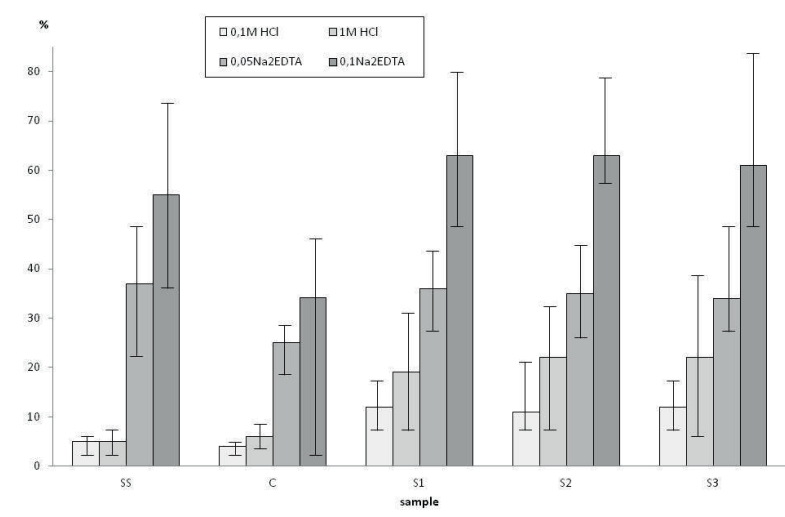

Fig. 1. Percentage of mobile form of cobalt extracted by different solutions

In order to determine the influence of selected parameters on the leaching of $\mathrm{Co}$, statistical analysis of the results was carried out. The correlation coefficient ( $r$ ) between the 'pseudo-total' content, $\mathrm{pH}$ and $\mathrm{OM}$ on leached forms of $\mathrm{Co}$ in soils, SS and composts (linear correlation) was calculated. In addition, multivariate 
regression analysis was performed, where the dependent variable was the content of leachable form of Co, whereas the independent variables were: Co 'pseudo-total' content, $\mathrm{pH}$, and the content of OM in the samples. The results of the statistical analysis are shown in Tables 2 and 3 .

In conjunction of obtaining the results below the limit of determination in the aqueous extracts in SS, composts and soils, statistical analysis were not calculated for those samples. Co in EDTA and $\mathrm{HCl}$ extractants were correlated positively and significantly with total metal content in analysed samples (Table 2). After taking into account additional factors, such as $\mathrm{pH}$ and $\mathrm{OM}$ content, the value of the $r$ was increased. This testifies to the influence of both factors on the mobility of Co. Higher $r$ was calculated for SS than for compost, whereas soils were characterised by low values of r. According to Greinert (2011) [7], the bioavailability of Co affects soil $\mathrm{pH}$ and redox conditions. Co in acidic solution may be found in dissolved forms, but in a neutral solution, as a part of a sorption complex. The solubility of $\mathrm{Co}$ in soils depends on the $\mathrm{pH}$, water content, redox potential, $\mathrm{OM}$ and granulometric composition, the content of manganese oxides, type of fertiliser and temperature. The elution of Co is increased by increasing acidity, hydration and iron content; while manganese reduces the mobility of cobalt [7].

Table 2. Correlation coefficients $(r)$ of linear and multivariate regression $(r, P<0.05)$ calculated for the relation between concentration of $\mathrm{Co}$ in extract solutions $\left(\mathrm{Co}_{(\text {extract })}\right)$ and 'pseudo-total' $\left(\mathrm{Co}_{\mathrm{p} \text {-total }}\right), \mathrm{pH}, \mathrm{OM}$ contents in samples

\begin{tabular}{|c|c|c|c|c|c|}
\hline & \multicolumn{5}{|c|}{ Type of extractant } \\
\hline & $\mathrm{H}_{2} \mathrm{O}$ & $\begin{array}{c}0.1 \mathrm{M} \\
\mathrm{HCl}\end{array}$ & $\begin{array}{l}1 \mathrm{M} \\
\mathrm{HCl}\end{array}$ & $\begin{array}{c}0.05 \mathrm{M} \\
\mathrm{Na}_{2} \text { EDTA }\end{array}$ & $\begin{array}{c}0.1 \mathrm{M} \\
\mathrm{Na}_{2} \text { EDTA }\end{array}$ \\
\hline \multicolumn{6}{|c|}{ Sewage sludge } \\
\hline $\begin{array}{c}\mathrm{Co}(\text { extract })=\left(\mathrm{Co}_{\mathrm{p} \text {-total }}\right) \\
\mathrm{Co}(\text { extract })=(\mathrm{pH}) \\
\mathrm{Co}(\text { extract })=(\mathrm{OM}) \\
\mathrm{Co}(\text { extract })=\left(\mathrm{Co}_{\mathrm{p} \text {-total }}\right)+(\mathrm{pH}) \\
\mathrm{Co}(\text { extract })=\left(\mathrm{Co}_{\text {p-total }}\right)+(\mathrm{OM}) \\
\mathrm{Co}(\text { extract })=\left(\mathrm{Co}_{\mathrm{p} \text {-total }}\right)+(\mathrm{pH})+(\mathrm{OM})\end{array}$ & $\begin{array}{l}- \\
- \\
- \\
- \\
-\end{array}$ & $\begin{array}{l}0.937 \\
0.358 \\
0.316 \\
0.937 \\
0.957 \\
\mathbf{0 . 9 5 8}\end{array}$ & $\begin{array}{l}0.932 \\
0.439 \\
0.499 \\
0.935 \\
0.932 \\
0.936\end{array}$ & $\begin{array}{l}\mathbf{0 . 9 8 7} \\
0.443 \\
0.605 \\
\mathbf{0 . 9 8 9} \\
\mathbf{0 . 9 9 3} \\
\mathbf{0 . 9 9 5}\end{array}$ & $\begin{array}{l}0.989 \\
0.457 \\
0.586 \\
0.992 \\
0.993 \\
0.996\end{array}$ \\
\hline \multicolumn{6}{|c|}{ Compost } \\
\hline $\begin{array}{c}\text { Co }(\text { extract })=(\text { Co } p \text {-total }) \\
\text { Co }(\text { extract })=(\mathrm{pH}) \\
\text { Co }(\text { extract })=(\mathrm{OM}) \\
\mathrm{Co}(\text { extract })=(\text { Co } p \text {-total })+(\mathrm{pH}) \\
\mathrm{Co}(\text { extract })=(\text { Co } p \text {-total })+(\mathrm{OM}) \\
\mathrm{Co}(\text { extract })=(\text { Co } p \text {-total })+(\mathrm{pH})+(\mathrm{OM})\end{array}$ & $\begin{array}{l}- \\
- \\
- \\
- \\
-\end{array}$ & $\begin{array}{c}0.681 \\
0.532 \\
-0.600 \\
0.750 \\
\mathbf{0 . 9 2 7} \\
\mathbf{0 . 9 2 3}\end{array}$ & $\begin{array}{l}\mathbf{0 . 8 5 1} \\
0.763 \\
0.129 \\
\mathbf{0 . 8 5 7} \\
\mathbf{0 . 8 5 7} \\
\mathbf{0 . 8 7 4}\end{array}$ & $\begin{array}{l}0.912 \\
0.967 \\
0.196 \\
0.967 \\
0.927 \\
0.967\end{array}$ & $\begin{array}{l}0.648 \\
0.725 \\
0.632 \\
0.732 \\
\mathbf{0 . 8 9 1} \\
\mathbf{0 . 8 9 4}\end{array}$ \\
\hline \multicolumn{6}{|c|}{ Soil 1} \\
\hline $\begin{array}{c}\text { Co }(\text { extract })=(\text { Co } p \text {-total }) \\
\text { Co }(\text { extract })=(p H) \\
\text { Co }(\text { extract })=(\mathrm{OM}) \\
\text { Co }(\text { extract })=(\text { Co } p \text {-total })+(p H) \\
\text { Co }(\text { extract })=(\text { Co } p \text {-total })+(\mathrm{OM}) \\
\text { Co }(\text { extract })=(\text { Co } p \text {-total })+(p H)+(O M)\end{array}$ & $\begin{array}{l}- \\
- \\
- \\
- \\
-\end{array}$ & $\begin{array}{l}0.123 \\
0.166 \\
0.186 \\
0.188 \\
0.257 \\
0.262\end{array}$ & $\begin{array}{l}-0.484 \\
0.138 \\
0.618 \\
0.545 \\
0.703 \\
0.704\end{array}$ & $\begin{array}{l}0.365 \\
0.284 \\
0.442 \\
0.420 \\
0.665 \\
0.666\end{array}$ & $\begin{array}{l}0.351 \\
0.208 \\
0.420 \\
0.420 \\
0.634 \\
0.641\end{array}$ \\
\hline \multicolumn{6}{|c|}{ Soil 2} \\
\hline $\begin{array}{c}\text { Co }(\text { extract })=(\text { Co } p \text {-total }) \\
\text { Co }(\text { extract })=(\mathrm{pH}) \\
\text { Co }(\text { extract })=(\mathrm{OM}) \\
\mathrm{Co}(\text { extract })=(\text { Co p-total })+(\mathrm{pH}) \\
\mathrm{Co}(\text { extract })=(\text { Co } p \text {-total })+(\mathrm{OM}) \\
\mathrm{Co}(\text { extract })=(\text { Co } \text {-total })+(\mathrm{pH})+(\mathrm{OM})\end{array}$ & $\begin{array}{l}- \\
- \\
- \\
- \\
-\end{array}$ & $\begin{array}{l}-0.367 \\
0.052 \\
0.086 \\
0.376 \\
0.373 \\
0.380\end{array}$ & $\begin{array}{l}-0.573 \\
0.208 \\
0.682 \\
0.573 \\
0.757 \\
0.759\end{array}$ & $\begin{array}{l}0.025 \\
0.210 \\
0.675 \\
0.234 \\
\mathbf{0 . 7 4 6} \\
\mathbf{0 . 7 5 8}\end{array}$ & $\begin{array}{l}-0.095 \\
0.252 \\
0.732 \\
0.252 \\
0.762 \\
\mathbf{0 . 7 7 4}\end{array}$ \\
\hline \multicolumn{6}{|c|}{ Soil 3} \\
\hline $\begin{array}{c}\mathrm{Co}(\text { extract })=(\text { Co } \mathrm{p} \text {-total }) \\
\mathrm{Co}(\text { extract })=(\mathrm{pH}) \\
\mathrm{Co}(\text { extract })=(\mathrm{OM}) \\
\mathrm{Co}(\text { extract })=(\text { Co } \text {-total })+(\mathrm{pH}) \\
\mathrm{Co}(\text { extract })=(\text { Co p-total })+(\mathrm{OM}) \\
\mathrm{Co}(\text { extract })=(\text { Co } p \text {-total })+(\mathrm{pH})+(\mathrm{OM})\end{array}$ & $\begin{array}{l}- \\
- \\
- \\
- \\
-\end{array}$ & $\begin{array}{l}0.003 \\
0.136 \\
0.039 \\
0.142 \\
0.044 \\
0.262\end{array}$ & $\begin{array}{c}-0.480 \\
-0.448 \\
0.412 \\
0.575 \\
0.531 \\
0.622\end{array}$ & $\begin{array}{c}0.058 \\
-0.311 \\
0.417 \\
0.351 \\
0.494 \\
0.614\end{array}$ & $\begin{array}{c}0.078 \\
-0.317 \\
0.413 \\
0.367 \\
0.501 \\
0.627\end{array}$ \\
\hline
\end{tabular}


Table 3. Correlation coefficients $(r)$ of linear regression $(r, P<0.05)$ between Co contents in extractants

\begin{tabular}{|c|c|c|c|}
\hline Extractant & $1 \mathrm{M} \mathrm{HCl}$ & $0.05 \mathrm{M} \mathrm{Na}_{2}$ EDTA & $0.1 \mathrm{M} \mathrm{Na}{ }_{2}$ EDTA \\
\hline $0.1 \mathrm{M} \mathrm{HCl}$ & $\begin{array}{c}\text { SS } r=0.778 \\
\text { C } r=0.683 \\
\text { S1 } r=-0.211 \\
\text { S2 } r=0.139 \\
\text { S3 } r=0.070\end{array}$ & $\begin{array}{c}\text { SS } r=0.875 \\
\text { C } r=0.605 \\
\text { S1 } r=-0.121 \\
\text { S2 } r=0.148 \\
\text { S3 } r=0.186\end{array}$ & $\begin{array}{c}\text { SS } r=0.883 \\
C r=0.230 \\
\text { S1 } r=-0.124 \\
\text { S2 } r=0.162 \\
\text { S3 } r=0.123\end{array}$ \\
\hline $1 \mathrm{M} \mathrm{HCl}$ & - & $\begin{array}{l}\text { SS } r=0.959 \\
\text { C } r=0.856 \\
\text { S1 } r=0.241 \\
\text { S2 } r=0.634 \\
\text { S3 } r=0.634\end{array}$ & $\begin{array}{l}\text { SS } r=0.962 \\
\text { C } r=0.800 \\
\text { S1 } r=0.271 \\
\text { S2 } r=0.331 \\
\text { S3 } r=0.628\end{array}$ \\
\hline 0.05M EDTA & - & - & $\begin{array}{c}\text { SS } r=0.999 \\
\text { C } r=0.827 \\
\text { S1 } r=0.984 \\
\text { S2 } r=0.980 \\
\text { S3 } r=0.991\end{array}$ \\
\hline
\end{tabular}

In addition, among others, the $r$ value was analysed (Table 3). Significant correlations were found between $\mathrm{Co}-\mathrm{HCl}$ and Co- $\mathrm{Na}_{2}$ EDTA concentrations in SS and compost samples $(r=0.800-0.962)$. The contents of Co extracted with $0.05 \mathrm{M}$ $\mathrm{Na}_{2}$ EDTA were highly correlated with the $0.1 \mathrm{M} \mathrm{Na} \mathrm{Na}_{2}$ EDTA $(r=0.827(\mathrm{Ct})-0.999(\mathrm{SS}))$. In the case of soil in the majority of cases, the relationship between the extracts was not statistically significant. Statistically significant correlation between the extracts of $0.05 \mathrm{M}$ and $0.1 \mathrm{M} \mathrm{Na} \mathrm{EDTA}_{2}$ in the soils samples were only determined. The lower $r$ were calculated between $1 \mathrm{M} \mathrm{HCl}$ and $0.05 \mathrm{M}$ or $0.1 \mathrm{M} \mathrm{Na} \mathrm{EDDT}_{2}$ in fertilised soils.

\section{CONCLUSIONS}

The studied soils were rich in Co. Co content in soils slightly depends on fertilisation with SS and compost. Cobalt leaching

\section{REFERENCES AND LEGAL ACT}

1. ANJU M., BANERJEE D.K. 2011. Associations of cadmium. zinc. and lead in soils from a lead and zinc mining area as studied by single and sequential extractions. Environmental Monitoring and Assessment 176: 67-85.

2. BHATTACHRYYA P., CHAKRABARTI K., CHAKRABORTY A., TRIPATHY S., KIM K., POWELL M.A. 2008. Cobalt and nickel uptake by rice and accumulation in soil amended with municipal solid waste compost. Ecotoxicology and Environmental Safety 69, 3: 506-512.

3. CHEN S., SUN L., CHAO L., ZHOU Q., SUN T. 2009. Estimation of Lead Bioavailability in Smelter-Contaminated Soils by Single and Sequential Extraction Procedure. Bulletin of Environmental Contamination and Toxicology 82, 1: 43-47.

4. DIATTA J.B., GRZEBISZ W. 1999. Evaluation of Chelating Agents as Heavy Metals Extractants in Agricultural Soils under Threat of Contamination. Polish Journal of Environmental Studies 8, 3: 149-154. from soils, sludges and composts depends on the type and concentration of the extractant. More of the metals were eluted using a chelating agent ( $\mathrm{Na}_{2}$ EDTA) than the $\mathrm{HCl}$.

'Pseudo-total' content, $\mathrm{pH}$ and $\mathrm{OM}$ level also affects leachability of Co. Co in soil is mainly bound with organic fraction and oxides of Fe-Mn. Therefore, it is gradually leached out of the soil. In Poland, there is a standardised content of this metal in sludge used for agricultural purposes. The Co content in the SS is usually several times higher than in typical organic fertilisers. Although the metal is part of the trace elements necessary for the growth of plants, the excess in the soil may affect toxicity. Therefore, when SS is used as fertiliser, it should be taken into account not only the overall metal content limited by law, but also other metals and the percentage of mobile forms.

5. GAWDZIK J.I. 2010. Specjacja metali ciężkich w osadzie ściekowym na przykładzie wybranej oczyszczalni komunalnej. Ochrona Środowiska 4, 32: 15-19.

6. GORLACH E., MAZUR T. 2001. Chemia rolna. PWN. Warszawa.

7. GREINERT A. 2011. Kobalt w środowisku przyrodniczym i antropogenicznym. Wydawnictwo Uniwersytetu Zielonogórskiego. Zielona Góra.

8. GREINERT A. 2008. Normy zawartości metali ciężkich w glebach w Polsce i UE w kontekście ich mobilności w warunkach presji urbanistycznej. Ekotoksykologia w Ochronie Środowiska: 121-128. Wyd. PZITS Oddział Dolnośląski.

9. JESKE A., GWOREK B. 2011. Przegląd metod oznaczania biodostępności i mobilności metali ciężkich w glebach. Ochrona Środowiska i Zasobów Naturalnych 49: 209-218.

10. KABATA - PENDIAS A., PENDIAS H. 1999. Biogeochemia pierwiastków śladowych. PWN. Warszawa. 
11. KHANMIRZAEI A., BAZARGAN K., MOEZZI A A., RICHARDS B.K., SHAHBAZI K. 2013. Single and Sequential Extraction of Cadmium in Some Highly Calcareous Soils of Southwestern Iran. Journal of Soil Science and Plant Nutrition 13, 1: 153-164.

12. LU A.X., ZHANG S.Z., SHAN X.Q., WANG S.X., WANG Z.W. 2003. Application of microwave extraction for the evaluation of bioavailability of rare earth element in soils. Chemosphere 54: 54-63.

13. MEERS E., DU LAING G., UNAMUNO V., RUTTENS A., VANGRONSVELD J., TACK F.M.G., VERLOO M.G. 2007. Comparison of cadmium extractability from soils by commonly used single extraction protocols. Geoderma 141 : 247-259.

14. MERCIK S. (red.). 2004. Chemia rolna. Podstawy teoretyczne i praktyczne. Wyd. SGGW. Warszawa.

15. PN-EN 12457-2:2006. Charakteryzowanie odpadów -- Wymywanie -- Badanie zgodności w odniesieniu do wymywania ziarnistych materiałów odpadowych i osadów. Część 2: Jednostopniowe badanie porcjowe przy stosunku cieczy do fazy stałej $10 \mathrm{l} / \mathrm{kg}$ w przypadku materiałów o wielkości cząstek poniżej $4 \mathrm{~mm}$ (bez redukcji lub z redukcją wielkości). PKN. 2006. Warszawa.

16. RAJMUND A., BOŻYM M. 2014. Ocena biodostepności metali ciężkich w kompostach i osadach ściekowych z wiejskiej oczyszczalni ścieków w aspekcie przyrodniczego wykorzystania. Inżynieria i Ochrona Środowiska. (w recenzji).

17. RAO C. R. M., SAHUQUILLO A., LOPEZ SANCHEZ J.F. 2008. A Review of the Different Methods Applied in Environmental Geochemistry For Single and Sequential Extraction of Trace Elements in Soils and Related Materials. Water Air Soil Pollution 189: 291-333.
18. SEGUIN. V., GAGNON. C., COURCHESNE. F. 2004. Changes in water extractable metals. $\mathrm{pH}$ and organic carbon concentrations at the soil-root interface of forested soils. Plant and Soil 260: 1-17.

19. SIUTA J., WASIAK G. 1991. Zasady gospodarki odpadami bytowymi w środowisku przyrodniczym. Instytut Ochrony Środowiska. Warszawa.

20. SYMANOWICZ B., KALEMBASA S. 2010. Wpływ odpadowych węgli brunatnych i osadów ściekowych oraz ich mieszanin na zawartość kobaltu litu i glinu w glebie i roślinach. Acta Agrophysica 15, 1: 167-175.

21. SZUMSKA M., GWOREK B. 2009. Metody oznaczania frakcji metali ciężkich $w$ osadach ściekowych. Ochrona Środowiska i Zasobów Naturalnych 41: 42-63.

22. ŚRODA K., KIJO-KLECZKOWSKA A., OTWINOWSKI H. 2013. Methods of disposal of sewage sludge. Archiwum Gospodarki Odpadami i Ochrony Środowiska 15, 2: 33-50.

23. ŚWIETLIK R., TROJANOWSKA M. 2008. Metody frakcjonowania chemicznego stosowane $\mathrm{w}$ badaniach środowiskowych. Monitoring Środowiska Przyrodniczego 9: 29-36.

24. URE A.M., QUEVAUVILLER P., MUNTAU H., GRIEPINK B. 1993. Speciation of heavy metals in soils and sediments. An account of the improvement and harmonization of extraction techniques undertaken under the auspices of the BCR of the Commission of the European Communities. International Journal of Environmental Analytical Chemistry 51: 135-151.

25. URE A.M. 1996. Single extraction schemes for soil analysis and related applications. The Science of the Total Environment 178: 3-10.

26. WILK M., GWOREK B. 2009. Metale ciężkie w osadach ściekowych. Ochrona Środowiska i Zasobów Naturalnych 39: 40-59. 